\title{
Racism and Migration
}

\author{
David Matas
}

How can we combat racism against refugees and migrants? The answer is, it depends. It depends on the sort of racism we are attempting to combat. Racism against migrants and refugees is both official and unofficial, structural and personal. Personal racism, verbal and physical attacks on individuals by other individuals, overt, and explicit discrimination are the most visible and extreme forms of racism. These forms of racism must be combated by techniques of prevention, such as education; and by techniques of cure, such as prosecution. Since personal form of racism can be violent, it is the most dangerous. But at least it is easy to see and easy to denounce.

Structural racism against migrants and refugees is more indirect. It is discrimination, both in the governmental and nongovernmental arena, in the supply of services, in hiring, in promoting, that is not overt. The motivation may be discriminatory, but nothing racist is said when discrimination is inflicted. The effects are nonetheless discriminatory. Statistics show the discrimination when nothing else does. Combating structural racism against migrants and refugees involves techniques such as affirmative action, reasonable accommodation and the establishment and involvement of human rights commissions. The antidote is directed against racism as such.

Official racism, that is policy racism against migrants and refugees, is the most sophisticated, the most subtle, and the most indirect type of racism. Like structural racism, it does not manifest itself explicitly. However, unlike structural racism, it is impossi-

David Matas, a Winnipeg based lawyer, is co-chair of the Canadian Helsinki-Watch Group, and president of the Canadian Council for Refugees. ble to demonstrate statistically, since there is no point of comparison. Structural racism can be demonstrated statistically by comparing the treatment of migrants and refugees with the treatment of nationals. Official racism against migrants and refugees cannot be demonstrated in the same way, since nationals are, by definition, neither migrants nor refugees. Migration and refugee policy never affects nationals.

Statistics can show discrimination between migrants and between refugees. Nationals of some countries require visas. Others do not. Nationals of some countries are put through secondary examination at airports. $\mathrm{Na}$ tionals of other countries are not. Visa posts are few and far between, and delays in processing visa applications are gargantuan in some areas of the world. Elsewhere, visa posts are plentiful and delays in granting visas are short. Refugee claimants from some countries are readily granted recognition, while refugee claimants from other countries, although fleeing similar levels of repression, are systematically denied recognition.

This sort of racism can be demonstrated by traditional methods. But where the racism is manifested in a policy that is directed against all migrants or all refugees, indiscriminately, these traditional methods fail. The terrain of debate shifts. The traditional anti-racist vocabulary, anti-racist techniques are of little use here. A different vocabulary and different techniques are needed. Debates revolve around the wisdom of policies which have racial impacts. The debates themselves are about everything but race. Racial impact looms in the background as a consequence. However, racial impact is not an express justification for the policies.

Debates about migration and refugee policies become surrogates for de- bates on racism. Racial impact is the result of which no one speaks but of which everyone knows. The terms of the debate mask the racial impact at stake. Migration and refugee policy has to be debated at two levels. There has to be a debate at the level of content. At all times, during the substantive debate, anti-racists must not forget the racial implications of migration and refugee policies.

Racism cannot be fought just by fighting racist expression, or racist attacks, or by combating discrimination in employment and services. Racism must also be fought by joining debates which, at least in appearance, are about subjects altogether different from race. Yet, the outcome of these debates has a definite racial impact.

Migration, or refugee outflows are by nature racial or ethnic. Migration or refugee outflows are the movement of people from a country where they are nationals to other countries where they are not nationals. Opposition to migration, to refugee protection, whatever the vocabulary used, is opposition to the arrival of the foreigner, the stranger. The opposition is strongest when the migrants are forced migrants, or refugees. Refugees arrive precipitously. They arrive any which way they can. They arrive in large numbers all at once. Because they are forced to flee, they have not planned to come. They have not planned to integrate in the country of arrival. They may know nothing of the language or culture of the country of arrival. Their reception and integration is not arranged in advance by local nationals.

To discourage them from arrival, refugees may not be allowed to work. But, if they cannot work, they are seen as a drain on the economy. When xenophobia exists, it is strongest against refugees. Refugee protection debates revolve, for example, around the scope of the refugee definition. In many

Refuge, Vol. 13, No. 8 (January 1994) 
countries, the refugee definition is narrowly interpreted, effectively denying protection to many real refugees. The substantive debate is a debate about the scope of the refugee definition, but the impact of the debate is racial. A broad interpretation means openness to those who are different. A narrow interpretation is saying no to strangers.

A second example of racism is the "credibility" debate. Refugee protection is often denied to claimants on the basis that they are not credible, that they are lying. This skepticism can reach epidemic proportions, denying protection to refugee claimants wholesale. Those concerned with refugee protection have to approach the issue of credibility at the substantive level, to argue for the proper application of sound principles when assessing credibility. Those concerned with racism must join this debate. Here, too, the impact is racial. The implication of large numbers of denials based on credibility assessment, is, after all, an assumption that those different from us are dishonest-an implication that must be resisted.

Yet another terrain of debate for refugee protection is the source country condition information. Refugee claimants are rejected on the grounds that conditions in the countries they have fled have changed, or that conditions are not as bad as they claim. This debate seems to be about nothing other than what is happening in the country of origin. In reality, the debate is also about whether the stranger can stay or must go home. Those who want to expel the stranger will paint an overly rosy picture of the situation in the country of origin. Those who wish to welcome the stranger must be prepared to combat this false optimism.

The unfairness of refugee procedures is another example of racism. Claimants are denied access to counsel; they are denied adequate interpretation; and they are not allowed hearings for their claims, or an opportunity to respond to objections before a decision is made. Decision makers are not independent from governments who use the determination procedure to enforce anti-refugee policies. Furthermore, there may be no possibility to appeal a negative decision.

Unfair procedures generate inaccurate results, and the inaccuracy is invariably on the side of those wishing to restrict entry. As a result, real refugees are often erroneously rejected as false claimants. Here the substantive debate is about the nature of procedures, what is fair, what is unfair, and what due process requires. I would not accuse everyone who advocates for stricter refugee controls of racist motives, but I would not absolve every such person either.

While many who argue for narrow interpretations of the refugee definition, strict credibility determinations, benign interpretations of country conditions, or rough and ready determination procedures are not motivated by racism, it would be naive to think that all those who argue against generous refugee protection policies have no racist intent. Racism by impact is often a polite form of racism by intent. Sophisticated racists know enough to keep their beliefs quiet. They know that open expressions of racism are not considered acceptable, so they go about being racist without voicing their opinion. Racism in refugee protection is an attitude that dares not speak its name. The injection of racist attitudes into refugee debates means that these debates are too important to be left to refugee experts. If racists go about the business of discrimination, without signalling their intent in advance, anti-racists must offer an cure.

The issues here may appear to be of apparent technicality, best left to experts. Certainly, there are expert opinions that are relevant. There are positions in this area over which experts may reasonably differ. However, the field must not be left to experts alone to combat racist tendencies. The public interest in combating racism is also important. Not every person in favour of stricter migration and refugee controls is a racist, but every racist is in favour of stricter migration and refugee controls. Racists are present in migration and refugee debates, argu- ing their side. Anti-racists must also be present, to argue the other side.

Yet another manner in which refugee protection is restricted is by deterrence and disincentive measures. Claimants are made to lead lives so miserable that they are deterred from making or sustaining claims. Mobility within the country of refuge is denied. Claimants may be detained or kept in camps. If not detained, they may not be allowed to work or go to school. They may be denied social assistance or welfare. Family unification from abroad is also prevented.

Inhumane treatment has to be combatted at the substantive level by the application of humanitarian principles. Given the context, there is every reason for having those who wish to combat racism engage in this debate. Perhaps the most dramatic form of denial of refugee protection is the denial of access. Countries of admission impose visa requirements on citizens of refugee producing countries. Admission to the country of destination is impossible without a visa granted abroad by the government of the country of destination and carriers are penalized for transporting those without proper documentation. The result is that planes, ships, trains and buses will not transport refugees fleeing feared persecution to countries of destination, unless the refugees have visas from the government of the country of destination. Yet, no government will grant a visa to allow a person to come forward to make a refugee claim.

Along with visa requirements and carrier sanctions is the designation of safe third countries. Refugees are forcibly returned to countries designated as safe through which the refugees have passed in transit to the country of destination. Airport zones are yet another mechanism used to deny access. Claimants are kept notionally outside the country of destination by being detained at airports until they are forcibly removed. The most visible form of denial of access is interdiction. Refugees are stopped on the high seas or overland by the government of the destination country or their agents and 
prevented from arriving and making claims.

Denial of access is the most dramatic form of denial of refugee protection, because it is numerically the most significant. For racists, it is the ideal solution. The stranger is not just expelled. The stranger is never allowed to arrive. Debates about carrier sanctions, visa requirements, airport zones, and interdiction may seem to be highly technical debates concerning domestic and international law. Certainly, they are more complicated than debates about racial violence. Yet, at the end of the day, the outcome of these technical debates is going to have as much impact on racial equality as the outcome tion in several countries is not restricted to claimants who arrive on their own initiative and are recognized as refugees. Governments admit refugees recognized as such by the UN and/or by visa posts abroad. Each year the UN attempts to place refugees identified as being in need of resettlement. Several governments accept those UN identified refugees and, in the case of a few governments, others besides.

However, the UN only identifies a small portion of the refugees in need of resettlement. Even this small portion is not, in fact, resettled. Despite the small numbers identified, there are always too many for the resettlement coun-

\section{Persons may flee from violations of human rights not consid- ered to be serious enough to bring the person within the refugee definition. For instance, a person may flee in order to avoid discrimination that has not degenerated to a level grave enough to make the person a (Convention) refugee. That person cannot be considered to be just a voluntary migrant.}

of these other simpler debates about overt or structural racism.

Refugee claimants who do manage to get access to countries of destination only to be rejected by the claims procedure are not automatically returned to the country of origin. Most, if not all, countries allow some rejected claimants to stay on humanitarian grounds. Many countries have a "B status" that allows claimants to stay without refugee status.

There is a whole host of problems associated with the decision to grant this secondary status. Criteria may be overly narrow. Due process may be denied here too. Status, when granted, may be only temporary and uncertain. The privileges that go along with the status may be overly restrictive, creating, in effect, another set of disincentives to discourage people from staying. Here is one more example of a debate where the substance has nothing to do with race, but the impact has everything to do with race. Here is one more terrain of debate anti-racists cannot afford to ignore. Refugee protec- tries. Those with racist motivation, who make every effort to prevent refugees from arriving to make claims; who treat claimants as miserably as possible to discourage the maintaining of claims; who falsify determination procedures to generate undeserved rejections; who do everything they can to ensure rejected claimants are not allowed to stay on humanitarian grounds; are obviously not going to turn around to encourage the admission of large numbers of refugees for resettlement from abroad. It should be just as obvious to anti-racists that, if they want to combat racism, they must work to ensure that refugees abroad who are in need of resettlement are in fact resettled.

Refugees are sometimes called "irregular migrants." That is one form the attack against refugees takes. The suggestion is that those claiming to be refugees are really motivated by something other than a need for protection; that the motivation is economic; that these persons have moved in an illegal, irregular way, in order to circumvent legal obstacles that would deny them entry.

One reason racist nationals promote refusal of asylum seekers is selfishness, to avoid sharing their standard of living with foreigners. The racism of nationals thus has an economic dimension, a desire to keep the national wealth from foreigners. This economic motivation is then projected onto asylum seekers. This is essentially a case of blaming the victim for his/her victimization. Asylum seekers are accused of the vice from which racist nationals who work to deny them entry suffer-circumventing the law out of greed. Because racist nationals have an economic motivation-to keep the country's wealth for nationals-they assume that asylum seekers have a similar motivation. Because racist nationals distort the law to deny refugees protection, they assume asylum seekers try to get round the law in order to immigrate.

In reality, the motivation for asylum seekers is quite different - the need for protection. In one sense, this projection of economic motives from racists onto asylum seekers is just a particular form the attack on the credibility of asylum seekers takes, and it can be combated as such. However, this dichotomy between refugees and irregular migrants masks another significant distinction, and one with significant implications-the distinction between forced migration and voluntary migration.

Not every person who falls outside the refugee definition is a voluntary migrant. A refugee is a person with a well founded fear of persecution for listed reasons. A person who has a well founded fear of persecution for a reason not on the list is not a refugee, but that person can hardly be considered a voluntary migrant.

Persecution is any serious violation of human rights. Persons may flee from violations of human rights not considered serious enough to bring the person within the refugee definition. For instance, a person may flee in order to avoid discrimination that has not degenerated to a level grave enough to 
make the person a refugee. That persor cannot be considered just a voluntary migrant.

Individuals may flee war zones in order to avoid the conflict. However, the notion of persecution in the refugee definition is individualized. While the refugee definition can encompass whole groups, there has to be a sense in which each member of the group is a potential target. When the flight is from random violence, the persons fleeing may not be refugees. They are also certainly not voluntary migrants. A person may move because of economic or environmental disasters. The move may not be just a matter of improving the quality of life, it may be a matter of survival. These people too are neither refugees nor voluntary migrants.

Involuntary migrants who are not refugees need help as much as refugees do. But unlike refugees, there is no international regime that offers protection. There are regional regimes that promise protection in Latin America and Africa, however, these regional regimes are of no help to those seeking protection outside of those regions. The plight of non-refugee involuntary migrants is ignored outside of Latin America and Africa. Such persons are simply categorized as irregular voluntary migrants.

There needs to be a regime to offer protection outside of Latin America and Africa to involuntary migrants who are not refugees. The racial implications of establishing this regime are obvious. Expanding the notion of protection to cover all involuntary migrants would expand the number of strangers offered resettlement abroad exponentially. Needless to say, racists would be opposed. Anti-racists should work to counter that opposition. The debate about racism and migration does not end with refugee protection. It does not end with the offer of a safe haven to all involuntary migrants. The existence of voluntary migration presents its own debates.

One debate is over nationality rights. In many countries, voluntary migrants are allowed to come, but not allowed to stay. If allowed to stay, they are not allowed to become nationals at all, or only with great difficulty. Their inability to become nationals means that they are residents without a voice in the country. Their marginalization becomes easier because of the society's reluctance to integrate them. Because they are not and often cannot become citizens, their fate is decided by others without their own participation in the decisions.

The rights of nationals leads us into debates over nationality and citizenship laws. Yet these debates are not just debates about the technicalities of citizenship laws, they are also debates about whether we welcome strangers or turn a cold shoulder to them. For voluntary migrants, a second area of debate is family unification. In principle, families should be united. Yet the laws of many countries prevent that unification. In the foreground, the debate is about such things as defining the family, or the standard of proof. Are brothers and sisters to be considered family members for the purpose of family unity? Does the right to family unity cover adult children or only non-adult children? Are spouses to be allowed unification only when the genuineness of the marriage is established beyond a reasonable doubt, or is a balance of probabilities sufficient? In the background, the debate is about race. Are we going to allow those who may seem alien to us to enter to be with their families, or are we not?

For voluntary migrants who do not seek family unification, difficulties of access are at their most extreme. For refugees, the regime of refugee protection offers at least an argument for access to countries of refuge. For involuntary migrants who are not refugees and voluntary migrants who seek family unification, humanitarian principles can support arguments for access. For voluntary migrants who do not claim family unification, neither refugee protection principles nor humanitarian principles are available.

There is, nonetheless, a human rights principle in play here, other than the right to equality and freedom from discrimination. It is the evolving right to freedom of movement. Freedom of movement is often recognized internally in domestic human rights instruments as a right granted to nationals. It is not yet generally accepted as an international human right.

Freedom of movement is a simple and direct way to allow access to refugees fleeing feared persecution, as well as to other involuntary migrants, however, it has a value far beyond that. It is also a statement that all are welcome, no matter from where they come. Promoting the right to international freedom of movement may be the hardest battle of all to fight. For those with racist tendencies, international freedom of movement is the ultimate horror. For those with an anti-racist commitment, international freedom of movement should be an ideal to be achieved.

Voluntary migrants, without family in the country of destination, are admitted on economic grounds, on the basis that their admission is beneficial to the economy of the admitting country. Here the substantive debate is over whether the arrival of migrants will lead to nationals losing jobs or gaining jobs, over whether migrants will go on welfare or be self-sufficient. The reflex of the racist is that migrants harm the economy and, ostensibly for that reason, should not be admitted. Anti-racists need to develop countervailing economic arguments to show how migrants benefit the economy in order to combat that racism.

During the Cold War, there was the fear of an invasion from the East, expressed by the phrase: "The Russians are coming." Now that the Cold War is over, this fear continues in another form. The fear is no longer of an armed invasion, but of an unarmed flood of migrants. The fear is still: "The Russians are coming."

Now that the Eastern European countries have raised the Iron Curtain that surrounded them, the West has brought down a new curtain, a Gold Curtain around itself. When Eastern Europeans could not come to the West because they were not allowed to 